ISSN 1392-3196 / e-ISSN 2335-8947

Zemdirbyste-Agriculture, vol. 107, No. 2 (2020), p. 161-170

DOI $10.13080 /$ z-a.2020.107.021

\title{
Drought stress response of Westerwolths ryegrass (Lolium multiflorum ssp. multiflorum) cultivars differing in their ploidy level
}

\author{
Olakunle Kelvin AKINROLUYO, Kristina JAŠKŪNĖ, Vilma KEMEŠYTĖ, \\ Gražina STATKEVIČIŪTĖ
}

Lithuanian Research Centre for Agriculture and Forestry, Institute of Agriculture

Instituto 1, Akademija, Kèdainiai distr., Lithuania

E-mail: kelvin.akinroluyo@lammc.lt

\begin{abstract}
Drought is one of the critical abiotic stresses that significantly affect agricultural production, and current models predict an increase in its severity and intensity in the future. Generally, polyploidy has been found to improve the resistance of plants to abiotic stress. Understanding the role of ploidy in resistance to drought was achieved by comparing the response between diploids and their respective induced autotetraploids of Westerwolths ryegrass (Lolium multiflorum ssp. multiflorum). Field trials were carried out in the 2017 and 2018 growing seasons, and mild drought simulation experiments in controlled conditions were carried out to validate the effect of chromosome duplication. Results obtained from morphological traits in the field experiment revealed that the induced tetraploids were significantly $(p<0.05)$ taller, had longer inflorescences and larger flag leaf area than their diploid counterparts, especially in the year 2018 characterized by the prolonged drought.

This study also revealed that the induced tetraploids produced more dry matter yield than their diploid progenitors, especially in drought periods. The induced tetraploids had significantly higher antiradical activity and phenolic content than the diploid progenitors in response to mild drought, and this significantly correlated with the plant performance in 2018 field trials, indicating that increased ploidy level plays an important role in conferring resistance to drought in Westerwolths ryegrass. Furthermore, the antiradical activity and total phenolic content proved to be a good tool to evaluate drought tolerance at the vegetative stage in Westerwolths ryegrass.
\end{abstract}

Key words: mild drought, morphological traits, phenolic contents, tetraploids.

\section{Introduction}

Many regions of the world are experiencing prolonged droughts that seriously threaten agricultural production. The frequency of various extreme climatological events is increasing due to climate change. All global climate models predict rising temperatures and consequently even higher risk of drought in many areas globally in the future either due to reduction in precipitation, an increase in evaporation or a combination of these factors (Dai, 2013). A huge concern is placed on the impact of climate change on staple food production (Trnka et al., 2015); however, abiotic stresses affect forage production as well, pressing farmers and breeders to search for means of adapting the grasslands to arising challenges (Ergon et al., 2018).

Plants have developed different mechanisms to tolerate drought such as dehydration avoidance and dehydration tolerance (Fang, Xiong, 2015). Dehydration avoidance occurs when plants slow down their growth rates. It involves various morphological and anatomical changes that reduce the loss of water through transpiration and also improve the uptake of water from the soil by modulation of root system architecture (Luo, 2010). Dehydration tolerance is when plants are able to maintain their normal function under low leaf water status (Yates et al., 2019). Plants usually do this by accumulating both inorganic and organic substances to improve water retention by reducing the osmotic potentials (Blum, Tuberosa, 2018).

At the molecular level, drought tolerance is a complex quantitative trait that involves the activation or suppression of many genes. Some of the genes are involved in antioxidation activity needed to produce substrates that reduce the elevated concentration of reactive oxygen species (ROS) arising due to drought (Zandalinas et al., 2018).

Westerwolths ryegrass (Lolium multiflorum ssp. multiflorum) is a forage grass with high palatability and digestibility. It is fast growing due to its annual nature and produces high first cut yields. Besides the cultivation of Westerwolths ryegrass for the high-quality green

Please use the following format when citing the article:

Akinroluyo O. K., Jaškūnè K., Kemešytè V., Statkevičiūtė G. 2020. Drought stress response of Westerwolths ryegrass (Lolium multiflorum ssp. multiflorum) cultivars differing in their ploidy level. Zemdirbyste-Agriculture, 107 (2): 161-170. DOI $10.13080 /$ z-a.2020.107.021 
feed or silage production, it can also be used as a catch crop (Humphreys et al., 2010). Westerwolths ryegrass as well as its close relatives perennial ryegrass (Lolium perenne L.) and Italian ryegrass (L. multiflorum. ssp. italicum) are self-incompatible and occur naturally as diploid $(2 \mathrm{n}=2 \mathrm{x}=14)$; however, autotetraploid induction is rather simple (Dabkevičienè et al., 2017). Tetraploid forage ryegrass cultivars are known to produce higher herbage yields that are higher in energy and sugar content (Burns et al., 2013; Kemesyte et al., 2017).

The response of perennial ryegrass to drought has been extensively studied. Bothe et al. (2018) developed a practicable phenotyping platform to assess the drought stress response of perennial ryegrass and to screen for drought tolerance in many diverse perennial ryegrass populations.

Polyploid plants can exhibit higher adaptability, increased vigour and resistance to unfavourable environmental factors compared to their diploid relatives (Sattler et al., 2016); yet some studies indicate that diploids are more resistant to abiotic stresses (Helgadóttir et al., 2018) or the differences are small (Kemesyte et al., 2017). Most research projects use plants with different pedigrees when exploring differences in yield, stress resistance and changes in transcriptome between diploids and tetraploids. This makes interpretation of the results more difficult - the changes in phenotypic traits or gene expression might be due to different genetic background instead of ploidy level. Comparing induced autotetraploids to their respective diploid parental lines helped to avoid this problem and gave more reliable insights into the effect of ploidy level on the performance of the plant.

The aim of the research is to compare the performance of diploid cultivars, induced autotetraploids and tetraploid cultivars of Westerwolths ryegrass (Lolium multiflorum ssp. multiflorum) under natural and simulated drought conditions.

\section{Materials and methods}

Plant material. Westerwolths ryegrass (Lolium multiflorum ssp. multiflorum) five diploid cultivars, five induced tetraploids and three tetraploid cultivars were used in this study (Table 1). Tetraploid induction was carried out as described in Akinroluyo et al. (2018). The second and third generations of induced tetraploids were used in this study.

Table 1. Westerwolths ryegrass cultivars and induced tetraploids used in the field trial and drought stress trial in a controlled environment

\begin{tabular}{cccc}
\hline Name & Ploidy & Origin & $\begin{array}{c}\text { Induced } \\
\text { tetraploid name }\end{array}$ \\
\hline Druva & diploid & Latvia & Druva-4× \\
Varpe & diploid & Lithuania & Varpe-4× \\
Magloire & diploid & France & Magloire-4× \\
Top speed & diploid & France & Top speed-4× \\
Grazer & diploid & Germany & Grazer-4× \\
Wesley & tetraploid & Denmark & - \\
Caremo & tetraploid & Denmark & - \\
Peleton & tetraploid & Denmark & - \\
\hline
\end{tabular}

Field trial. The experiment was carried out in the fields of Institute of Agriculture, Lithuania Research Centre for Agriculture and Forestry $\left(55^{\circ} 40^{\prime} \mathrm{N}, 23^{\circ} 87^{\prime}\right.$ E) during the 2017 and 2018 growing seasons. The field experiment was established in three replicates in a randomized complete block design on $25^{\text {th }}$ May in 2017 and $9^{\text {th }}$ May in 2018, and each population / cultivar was represented by 20 plants per replicate. The soil of the experimental fields was Endocalcaric-Epihypogleyic Cambisol (WRB, 2014) characterized by a homogeneous texture, $\mathrm{pH}_{\mathrm{KCl}} 7.2$, humus content $1.74 \%$, available $\mathrm{P}_{2} \mathrm{O}_{5}$ $175 \mathrm{mg} \mathrm{kg}^{-1}$ and $\mathrm{K}_{2} \mathrm{O} 157 \mathrm{mg} \mathrm{kg}^{-1}$. Fertilizers $\mathrm{N}_{30} \mathrm{P}_{50} \mathrm{~K}_{70}$ and $\mathrm{N}_{45}$ were applied before sowing and after cuts.

Plant height $(\mathrm{cm})$, flag leaf area $\left(\mathrm{cm}^{2}\right)$ and inflorescence length $(\mathrm{cm})$ were measured when the heading stage of Westerwolths ryegrass was completed (BBCH 59). Ten plants per replicate, three flag leaves and inflorescences per plant were measured using image processing program ImageJ (Schneider et al., 2012). Fresh plant biomass was collected after regrowth from the first cut, dried and weighed to obtain the dry matter yield from each cultivar and the induced tetraploid.

The 2017 and 2018 growing seasons in Lithuania had different climatic conditions, especially in terms of the amount of rainfall and temperature, as shown in Figure 1. The summer of 2017 was rainy and cool, and the mean temperatures reached $20^{\circ} \mathrm{C}$ only at the end of July, whereas 2018 was much warmer, with less precipitation and lower air humidity; hence plants grown during 2018 were exposed to drought periods compared to the preceding growing season.

Mild drought simulation in the controlled environment. Five diploid cultivars, their respective induced tetraploids and three tetraploid cultivars were used in the drought simulation experiment (Table 1). The seeds were germinated on filter paper, and seedlings were allowed to grow for seven days before transplanting them to the round plastic pots (diameter $9 \mathrm{~cm}$, height $8 \mathrm{~cm}$ ) filled with $350 \mathrm{~g}$ sandy soil ( $54 \%$ compost, $32 \%$ sand and $14 \%$ peat), five plants per pot, four pots per population / cultivar. The pots were placed at random in the phytotron, set to $24^{\circ} \mathrm{C}$ during the day and $18^{\circ} \mathrm{C}$ at night, a $16 / 8$ hour photo-period and relative air humidity of $60 \%$. The plants were watered for two weeks and excess water was drained from holes at the base of the pots. Seven days before inducing mild drought, $100 \mathrm{ml}$ of water was added to each pot at the same time of the day to enable the plants to carry out their normal physiological functions. This was done to avoid excess water in the soil while preparing for drought initiation.

To investigate the effect of mild drought, 10 $\mathrm{ml}$ of water was added to each pot daily for five days. Five new unfolding leaves were marked at the nodes on the first day and the leaf elongation was recorded daily at the same time. Leaf wilting was also observed at the end of the mild drought simulation and scored from no wilting to severely wilted: 1 - no sign of wilting, $6-$ severely wilted. The experiment was carried out in three replicates.

Determination of the relative water content and chlorophyll fluorescence ratio. The relative water content (RWC) of leaves was determined at the end of the drought treatment. Leaf samples were collected from each population / cultivar and weighed immediately to obtain the fresh weight $(\mathrm{FW})$. The leaf samples were transferred to plastic sacks containing water and left for $6 \mathrm{~h}$ before obtaining the turgid weight (TW). Finally, the leaf samples were blotted dry and placed in an oven at $70^{\circ} \mathrm{C}$ for $72 \mathrm{~h}$ and weighed to obtain the dry weight (DW). The RWC was calculated using the Smart and Bingham (1974) formula:

$$
\mathrm{RWC} \%=100[(\mathrm{FW}-\mathrm{DW}) /(\mathrm{TW}-\mathrm{DW})] \text {. }
$$



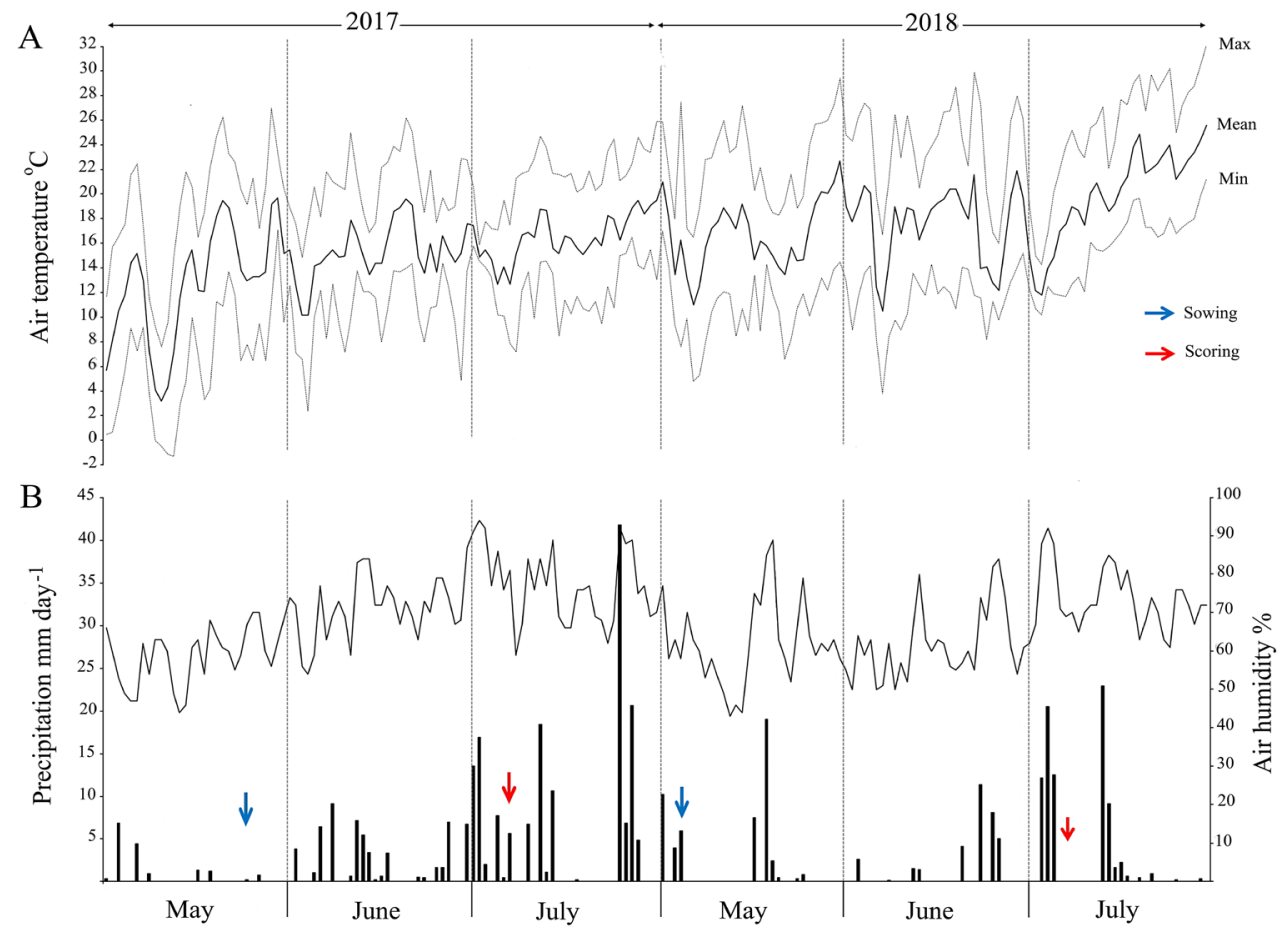

Figure 1. Meteorological conditions during 2017 and 2018

The chlorophyll fluorescence: the ratio of the variable fluorescence (Fv) and maximum fluorescence (Fm), was measured using a chlorophyll fluorometer OS30p+ (Opti-Sciences Inc., USA).

Antiradical activity measurement. 2,2-diphenyl-1-picrylhydrazyl (DDPH) free radical scavenging activity was determined by modifying the method described in Brand-Williams et al. (1995). The leaf samples were collected after mild drought and dried in an oven at $40^{\circ} \mathrm{C}$ for 4 days, homogenised and $0.5 \mathrm{~g}$ of the homogenised leaves was suspended in $70 \% \mathrm{v} / \mathrm{v}$ methanol. The extraction was done in a Sonorex Digital $10 \mathrm{P}$ ultrasonic bath (Bandelin Electronic $\mathrm{GmbH}$ and Co. $\mathrm{KG}$, Germany) for $60 \mathrm{~min}$ at $50^{\circ} \mathrm{C}$ and $480 \mathrm{~W}$. Two $\mathrm{ml}$ of DDPH solution in $70 \% \mathrm{v} / \mathrm{v}$ methanol was mixed in $2 \mu \mathrm{L}$ methanol extract. The reduction in absorbance at $515 \mathrm{~nm}$ was measured and expressed as Trolox equivalent antioxidant capacity.

Determination of total phenolic content. The total phenolic content was determined by modifying the methods described by Blainski et al. (2013). Spectrophotometric measurements were carried out with a Genesys-10 UV/VIS spectrophotometer (Thermo Spectronic, USA). The total phenolic content (mg GAE $\left.100 \mathrm{~g}^{-1} \mathrm{DW}\right)$ in the methanol extract $(99.0 \%, \mathrm{v} / \mathrm{v})$ of Westerwolths ryegrass leaves was determined by the
Folin-Ciocalteu method and expressed as gallic acid equivalents (GAE). The reduction in absorbance was measured at $715 \mathrm{~nm}$.

Statistical analysis. Pairwise $t$-test, analysis of variance (ANOVA) with post hoc Duncan multiple range tests were calculated using software $S A S$ (SAS Institute Inc., USA). Pearson's correlation coefficients were used to investigate relationships between selected variables. Mean $\pm \mathrm{SE}$ (standard error of mean) were used to describe the variability of measurements.

\section{Results}

Analysis of variance (ANOVA). The year, ploidy level and cultivars were taken as the main factors (data not shown). The effect of ploidy and cultivars was not significant for the morphological traits, but the year effect was highly significant $(p \leq 0.01)$. This indicated that the different weather conditions in 2017 and 2018 had the largest effect on the morphological traits. To determine the effect of ploidy on the morphological traits, the model cultivar + ploidy + replicate + cultivar $\times$ ploidy was applied for each year separately. The ploidy level and cultivar were considered as fixed factors. Results of the ploidy, cultivar and their interaction effect analysis are presented in Table 2.

Table 2. The effect of ploidy and its interaction effects on the Westerwolths ryegrass traits between diploids and induced tetraploids as indicated by the $F$ values

\begin{tabular}{cccccc}
\hline Trait & Year & $\mathrm{C}(\mathrm{df}=4)$ & $\mathrm{P}(\mathrm{df}=1)$ & $\mathrm{R}(\mathrm{df}=2)$ & $\mathrm{C} \times \mathrm{P}(\mathrm{df}=4)$ \\
\hline \multirow{2}{*}{ Plant height } & 2017 & $12.94^{* *}$ & 1.30 & $5.64^{* *}$ & $5.64^{* *}$ \\
& 2018 & $17.96^{* *}$ & $12.82^{* *}$ & 3.20 & $40.43^{* *}$ \\
\hline \multirow{2}{*}{ Flag leaf area } & 2017 & $12.62^{* *}$ & 1.64 & 2.26 & $41.46^{* *}$ \\
& 2018 & $4.23^{* *}$ & $102.66^{* *}$ & 0.63 & $74.15^{* *}$ \\
\hline Inflorescence & 2017 & $37.14^{* *}$ & $14.74^{* *}$ & 0.95 & $58.04^{* *}$ \\
length & 2018 & $68.72^{* *}$ & $168.14^{* *}$ & 0.67 & $177.52^{* *}$ \\
\hline
\end{tabular}

Note. $\mathrm{C}$ - cultivar, $\mathrm{P}$ - ploidy level, $\mathrm{R}$ - replicate, $\mathrm{df}$ - degree of freedom; ** - differences significant at $p \leq 0.01$. 
Comparison of the morphological traits between the induced tetraploids and diploid and tetraploid cultivars in the field trials. Plant height. No significant difference $(p>0.05)$ was observed in the plant height between the diploids and their respective induced tetraploids in 2017 field trials except in the cultivar 'Druva', whose diploids were significantly higher $(p \leq 0.05)$ than the induced tetraploid counterparts (Fig. 2). The tetraploid cultivars performed better and were significantly higher than both the diploid cultivars and induced tetraploids. However, in 2018 that had lower amount of rainfall and increased temperatures during the growing season, significant differences $(p \leq 0.05)$ were observed in the plant height between diploids and induced tetraploids with most of the induced tetraploids performing better and showing higher plant vigour than their diploid progenitors. The induced tetraploids had similar plant height with the tetraploid cultivars in 2018.
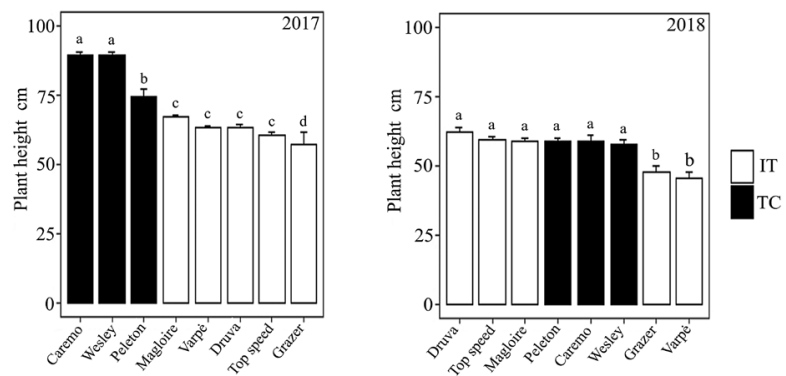

Induced tetraploids and tetraploid cultivars

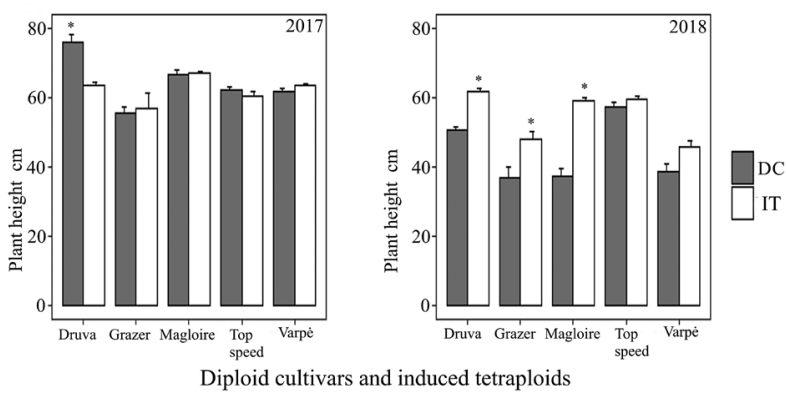

Note. Data shown as mean \pm standard error of three replicates * - differences significant at $p \leq 0.05$ pairwise $t$-test between diploids and their respective induced tetraploids; different letters indicate significant differences at $p \leq 0.05$ Duncan's multiple range tests.

Figure 2. The plant height of induced tetraploids (IT), tetraploid cultivars (TC) and diploid cultivars (DC)

Flag leaf area. The variations in the area of the flag leaf in diploid cultivars, their respective induced tetraploids and tetraploid cultivars were evaluated. The induced tetraploids had flag leaves with larger surface areas than the diploid cultivars in both growing seasons. However, drought periods in 2018 affected the flag leaf area of both cytotypes (Fig. 3). The tetraploid cultivars had flag leaves with larger surface areas than most of the induced tetraploids.

Inflorescence length. The induced tetraploids also had a higher inflorescence length in both years when compared to their parental diploids except in the cultivar 'Top speed', as shown in Figure 4. Drought significantly affected the inflorescence length of both cytotypes in the second year of investigation. However, most of the tetraploid cultivars have longer inflorescences than the induced tetraploids in both growing seasons.
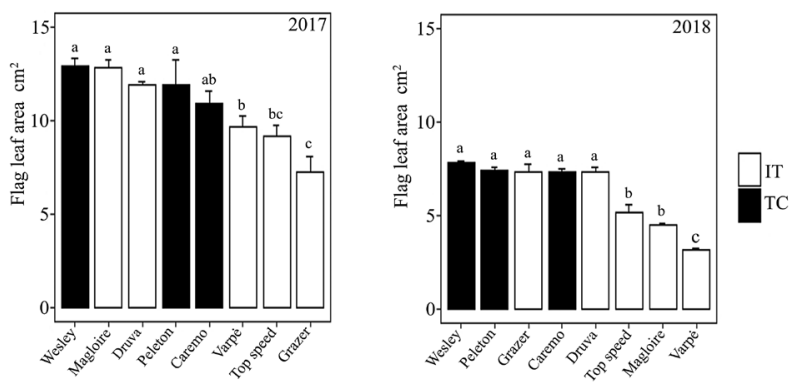

Induced tetraploids and tetraploid cultivars

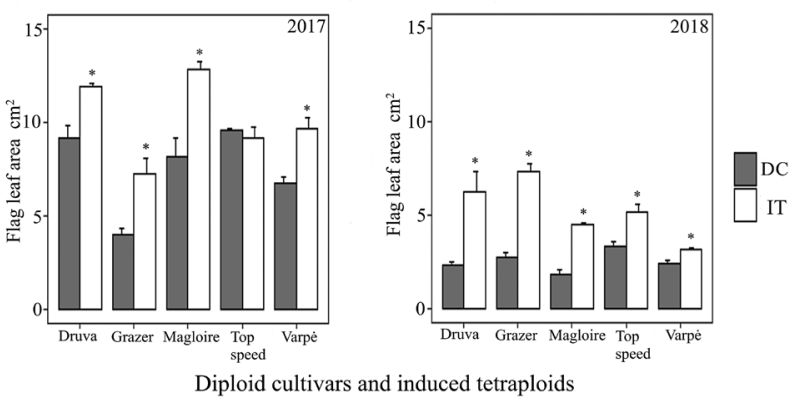

Explanation under Figure 2

Figure 3. The flag leaf area of induced tetraploids (IT), tetraploid cultivars (TC) and diploid cultivars (DC)
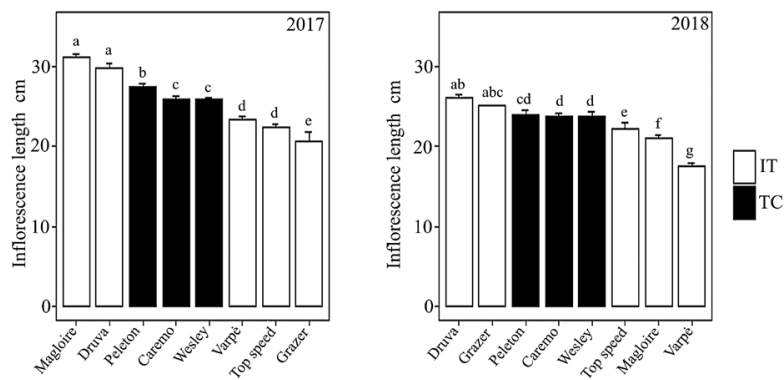

Induced tetraploids and tetraploid cultivars

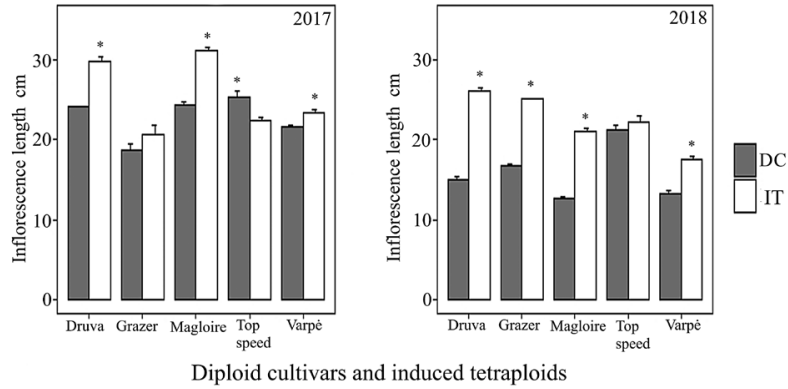

Explanation under Figure 2

Figure 4. The inflorescence length of induced tetraploids (IT), tetraploid cultivars (TC) and diploid cultivars (DC)

Dry matter yield (DMY) of induced tetraploids and diploid cultivars. As seen in Figure 5, the induced tetraploid did not produce higher dry matter yield than the diploid cultivars in 2017; however, the tetraploid cultivars produced more dry matter yield than both the diploid cultivars and induced tetraploids. Although drought appeared to reduce the DMY of the diploid cultivars and tetraploid cultivars in 2018, the induced tetraploids appeared to be more stable and performed better than their diploid progenitors, producing significant higher dry matter yields. 
Physiological and morphological response to mild drought in controlled conditions. The phenolic content and antiradical activity were found to respond to mild drought in both diploids and the induced tetraploids. The results showed that the induced tetraploids produced significantly more phenolic compounds and also had higher antiradical activity in response to mild drought $(p \leq 0.05)$ than their diploid progenitors, as shown in Figure 6.
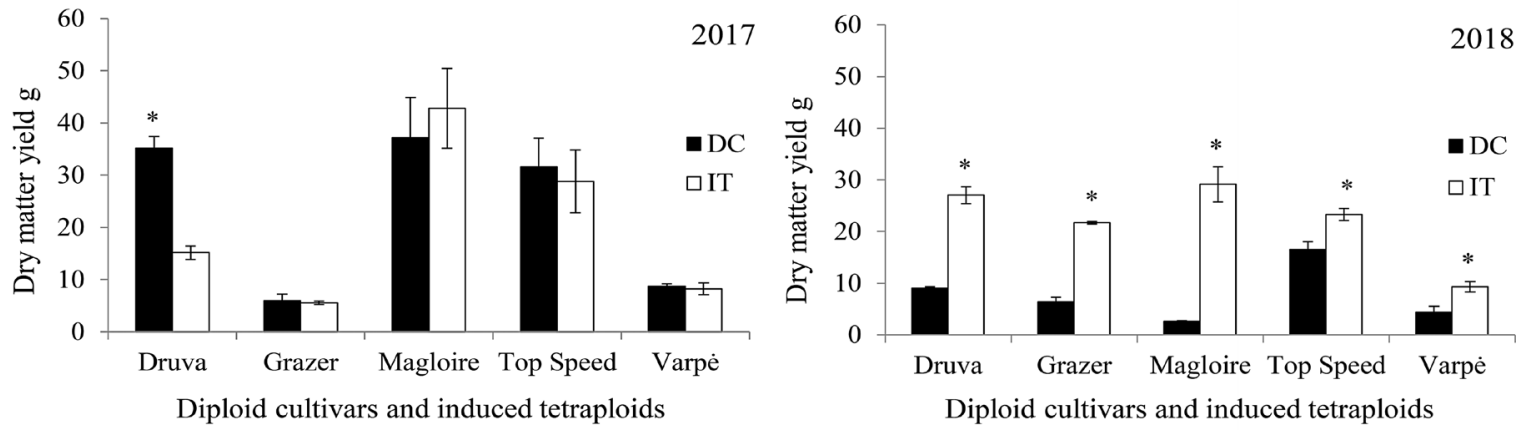

Explanation under Figure 2

Figure 5. The dry matter yield between the diploid cultivars (DC) and the induced tetraploids (IT) in 2017 and 2018 field trials

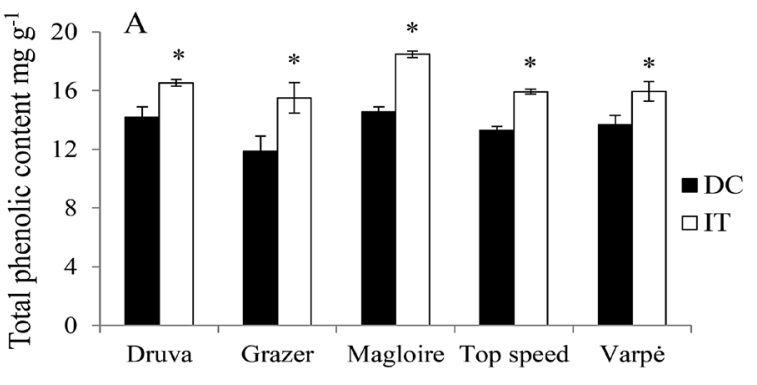

Diploid cultivars and induced tetraploids

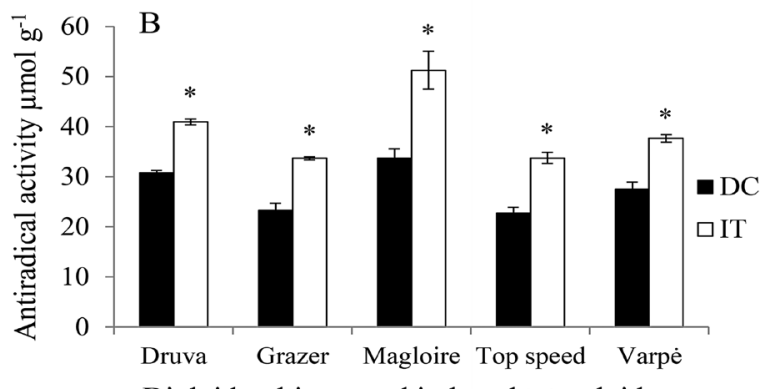

Diploid cultivars and induced tetraploids

Note. Data shown as mean \pm standard error of four replicates; ${ }^{*}$ - differences significant at $p \leq 0.05$ pairwise $t$-test between diploids and their respective induced tetraploids.

Figure 6. The total phenolic content (A) and antiradical activity (B) of diploid cultivars (DC) and induced tetraploids (IT) after 5 days of mild drought

The leaf elongation was measured daily, growth reduction, relative water content, the chlorophyll fluorescence ratio and the wilting score were determined at the end of the mild drought simulation experiment; the data is presented in Figure 7 and Table 3.

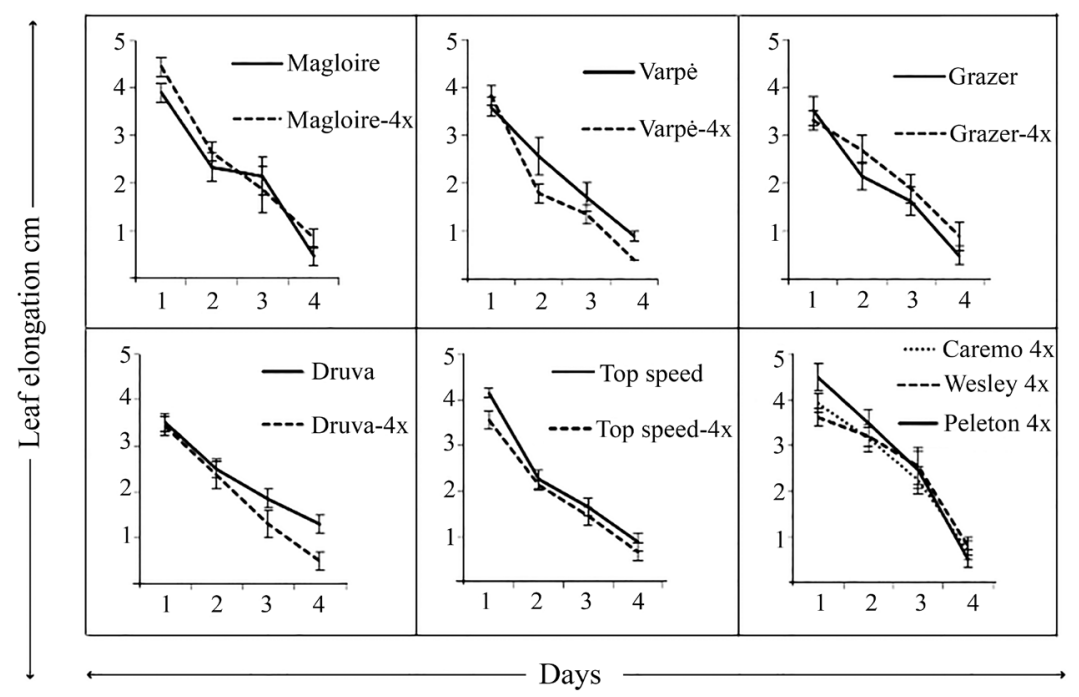

Note. Data shown as mean \pm standard error of three replicates.

Figure 7. Average daily leaf elongation in diploid cultivars, induced tetraploids and tetraploid cultivars after 5 days of mild drought 
Table 3. Comparison of leaf length, relative water content, chlorophyll fluorescence ratio (Fv:Fm) and wilting score of diploid cultivars, induced tetraploids and tetraploid cultivars after 5 days of mild drought

\begin{tabular}{|c|c|c|c|c|c|c|}
\hline $\begin{array}{l}\text { Population / } \\
\text { cultivar }\end{array}$ & $\begin{array}{l}\text { Leaf length } \\
\mathrm{cm}\end{array}$ & $\begin{array}{l}\text { Leaf length } \\
\text { control } \\
\mathrm{cm}\end{array}$ & $\begin{array}{c}\text { Leaf length } \\
\text { reduction } \\
\%\end{array}$ & $\begin{array}{c}\text { Relative water } \\
\text { content } \\
\%\end{array}$ & Fv:Fm & $\begin{array}{l}\text { Wilting } \\
\text { score }\end{array}$ \\
\hline Magloire $2 \times$ & $8.8 \pm 0.15$ & $13 \pm 0.24$ & $32 \pm 0.00$ & $71.8 \pm 0.82$ & $0.51 \pm 0.03$ & 5 \\
\hline Magloire- $4 \times$ & $9.8 \pm 0.31^{*}$ & $15 \pm 0.29 *$ & $35 \pm 0.02$ & $79.6 \pm 0.92 *$ & $0.63 \pm 0.00^{*}$ & 2 \\
\hline Varpé $2 \times$ & $8.8 \pm 1.10$ & $12.3 \pm 0.49$ & $29 \pm 0.07$ & $80.5 \pm 0.30$ & $0.61 \pm 0.03$ & 4 \\
\hline Varpè-4× & $7.4 \pm 0.90$ & $14.2 \pm 0.28^{*}$ & $48 \pm 0.05^{*}$ & $79.5 \pm 0.48$ & $0.62 \pm 0.03$ & 3 \\
\hline Grazer $2 \times$ & $7.8 \pm 0.24$ & $11.2 \pm 0.32$ & $31 \pm 0.04$ & $79.5 \pm 0.47^{*}$ & $0.65 \pm 0.00$ & 3 \\
\hline Grazer-4× & $8.8 \pm 0.19^{*}$ & $14.7 \pm 0.37^{*}$ & $40 \pm 0.04^{*}$ & $73.6 \pm 1.11$ & $0.62 \pm 0.01$ & 6 \\
\hline Top speed $2 \times$ & $8.3 \pm 0.21$ & $11.7 \pm 0.22$ & $31 \pm 0.00$ & $80.5 \pm 0.96$ & $0.65 \pm 0.01 *$ & 4 \\
\hline Top speed-4× & $8.1 \pm 0.20$ & $13.7 \pm 0.28^{*}$ & $42 \pm 0.00^{*}$ & $78.1 \pm 0.96$ & $0.53 \pm 0.02$ & 3 \\
\hline Druva $2 \times$ & $9.2 \pm 0.18$ & $11.7 \pm 0.35$ & $23 \pm 0.01$ & $75.7 \pm 0.84$ & $0.64 \pm 0.02$ & 3 \\
\hline Druva-4× & $7.6 \pm 0.62$ & $13.4 \pm 0.28^{*}$ & $44 \pm 0.03^{*}$ & $77.2 \pm 0.93$ & $0.64 \pm 0.01$ & 5 \\
\hline Caremo & $10.0 \pm 0.17$ & $14.8 \pm 0.19$ & $32 \pm 0.02$ & $82.9 \pm 0.00$ & $0.59 \pm 0.05$ & 3 \\
\hline Wesley & $10.2 \pm 0.10$ & $13.6 \pm 0.22$ & $25 \pm 0.02$ & $81.9 \pm 1.28$ & $0.58 \pm 0.00$ & 3 \\
\hline Peleton & $11.0 \pm 0.24$ & $14.4 \pm 0.43$ & $24 \pm 0.01$ & $81.0 \pm 0.96$ & $0.67 \pm 0.01$ & 2 \\
\hline
\end{tabular}

Explanation under Figure 2

The decrease in leaf elongation of plants grown under stress conditions compared to control plants was evaluated. Four induced tetraploids had a significant reduction in leaf elongation compared to their diploid progenitors $(p \leq 0.05)$. This reduction in leaf elongation correlates with the total phenolic content in the leaves $(r=0.45, p \leq 0.01)$, as shown in Table 4 .

Table 4. Correlation coefficients matrix among the physiological traits in response to mild drought of five diploid cultivars, their respective induced tetraploids and three tetraploid cultivars

\begin{tabular}{cccccc}
\hline & $\begin{array}{c}\text { Leaf length } \\
\text { reduction }\end{array}$ & $\begin{array}{c}\text { Relative water } \\
\text { content }\end{array}$ & $\begin{array}{c}\text { Chlorophyll } \\
\text { fluorescence ratio } \\
\text { (Fv:Fm) }\end{array}$ & $\begin{array}{c}\text { Phenolic } \\
\text { content }\end{array}$ & $\begin{array}{c}\text { Antiradical } \\
\text { activity }\end{array}$ \\
\hline Leaf length reduction & 1 & -0.19 & -0.09 & $0.45^{* *}$ & 0.28 \\
Relative water content & -0.19 & 1 & 0.17 & 0.17 & 0.14 \\
Chlorophyll fluorescence ratio (Fv:Fm) & -0.09 & 0.17 & 1 & -0.06 & 0 \\
Phenolic content & $0.45^{* *}$ & 0.17 & -0.06 & 1 & $0.75^{* *}$ \\
Antiradical activity & 0.28 & 0.14 & 0 & $0.75^{* *}$ & 1 \\
\hline
\end{tabular}

** - significant at $p \leq 0.01$

Variations in the relative water content and chlorophyll were observed between the cytotypes. The weight of the shoot biomass in each pot was measured at the end of mild drought simulation, and most of the induced tetraploids had significantly more biomass $(p \leq 0.05)$ compared to their diploid progenitors except in the cultivar 'Top speed', as shown in Figure 8.

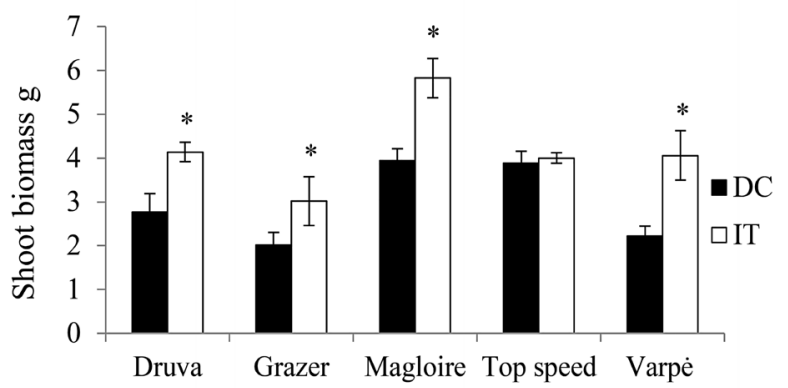

Diploid cultivars and induced tetraploids

Note. Data shown as mean \pm standard error of four replicates; * - differences significant at $p \leq 0.05$ pairwise $t$-test between diploids and their respective induced tetraploids.

Figure 8. The shoot biomass of diploid cultivars (DC) and induced tetraploids (IT) after 5 days of mild drought
A significant medium positive correlation $(p \leq$ $0.01)$ was found between morphological trait measures in 2018 field trials and the phenolic content during mild drought in controlled conditions. Similar relationship was also found between the antiradical activity and morphological traits, as shown in Table 5.

Table 5. Correlation coefficients matrix between physiological responses during mild drought in controlled conditions and morphological traits in the 2018 growing season in the field

\begin{tabular}{ccccc}
\hline & $\begin{array}{c}\text { Plant } \\
\text { height }\end{array}$ & $\begin{array}{c}\text { Flag } \\
\text { leaf } \\
\text { area }\end{array}$ & $\begin{array}{c}\text { Inflores- } \\
\text { cence } \\
\text { length }\end{array}$ & $\begin{array}{c}\text { Dry } \\
\text { matter } \\
\text { yield }\end{array}$ \\
\hline Antiradical activity & $0.49 * *$ & $0.46^{* *}$ & $0.41 * *$ & $0.60 * *$ \\
Phenolic content & $0.53 * *$ & $0.53 * *$ & $0.51 * *$ & $0.58 * *$ \\
\hline$* *$ - significant at $p \leq 0.01$ & & &
\end{tabular}

\section{Discussion}

The prominence of polyploids in grass species is an indicator that polyploidy has some adaptive importance. Polyploidy has been widely studied in many plant species and is known to often demonstrate phenotypes that are not present in the diploid progenitors (Ramsey, Schemske, 2002). These polyploidy induced 
traits such as drought tolerance and increased biomass production could be advantageous in many agricultural processes. Although the mechanism by which the novel traits are manifested in polyploid plants is still not properly understood, neofunctionalisation of genes has been a long-standing theory according to which genes acquire a new function after gene duplication (Osborn et al., 2003).

In both years of investigation, the diploid and tetraploid cultivars demonstrated variation in their growth patterns. In 2017 field trials, the tetraploid cultivars were higher than both the induced tetraploids and the diploid cultivars. The functional divergence resulting from polyploidisation often confers selective advantages to polyploids (Osborn et al., 2003). These advantages are rarely immediate but occur over a period of time, and this could be a reason why no significant difference was observed in the plant height of induced tetraploids and diploid progenitors.

However, other studies have reported that the effect of polyploidisation is immediate. The tetraploid cultivars may have performed better than the induced tetraploids, especially in terms of plant height as a result of genomic stability and epigenetic changes such as DNA methylation and histone modification, which can be inherited in gene expression (Liu, Wendel, 2003). Dar et al. (2013) reported that the DNA methylation changes increased from the first generation of induced tetraploids to the fourth generation in Phlox drummondii. DNA methylation has also been found to play a role in plant development, genome stabilisation and the expression of redundant genes (Adams et al., 2003; Aversano et al., 2013). In essence, the induced tetraploids could perform better in subsequent generations when the DNA methylation increases and the genome stabilises.

The leaf growth is a dynamic process often involving independent pathways that direct the cell components (Gao et al., 2016). Previous studies have shown that autotetraploids of Lolium species had long leaves due to the increase in cell length and a faster rate of cell elongation (Sugiyama, 2005). The increase in the flag leaf area of the induced tetraploids compared to the diploid progenitors can likely be attributed to an increase in the size of cells as a result of genome duplication and a faster rate of elongation. Also, it could be suggested that DNA methylation resulting from chromosome duplication could lead to a differential gene expression level resulting in the observed changes in the plant morphology of tetraploids. In the present study, the effect of drought on the flag leaf was clearly visible in both cytotypes. The flag leaves in 2018 field trials had a smaller surface area in both cytotypes when compared to the result obtained in the previous year. This reduction in the area of the flag leaf is an adaptive response to drought. However, the reduction in the flag leaf area was more profound in the diploid cultivars. The induced tetraploids also had longer inflorescences in both years when compared to their parental diploid except in the cultivar 'Top speed'.

Renny-Byfield and Wendel (2014) suggested that immediate and long-term disturbances in the genome, transcriptome and epigenome are intrinsic to polyploidy. This may explain why the induced tetraploids were not taller than their respective diploid progenitors in the 2017 growing season and probably why the tetraploid cultivars had better performance compared to the induced tetraploids in 2017. The genetic makeup of the cultivars / populations appears to contribute to the variations observed in the field performance of the cultivars / induced tetraploids.
Generally, there is an increase in the demand for forage to meet animal nutrient requirements. In polyploid plants, increase in chromosome number, genomic interaction and genetic alteration usually leads to plants with superior characteristics. This makes polyploidisation a credible approach to crop improvement. Polyploid inductions have been undertaken in many plants and have been found to improve plant productivity. High levels of heterozygosity are usually expected in autotetraploids compared to their diploid counterparts due to polysomic inheritance (Soltis et al., 2003), and the genomes of polyploid plants stabilise as the generation progresses. In addition, the high level of heterozygosity has been positively correlated to increments in vigour in alfalfa (Katepa-Mupondwa et al., 2002). This may explain why the induced tetraploids did not produce higher DMY than their respective diploid progenitors in the 2017 growing season. The induced tetraploids produced more DMY than the diploid progenitors in the 2018 growing season, characterised by higher average temperatures and extended period of drought.

Drought generally increases the production of reactive oxygen species (ROS) in plants, and if cells are poorly protected, the ROS could damage membrane lipids, proteins and also DNA molecules, leading to cell death. Redox homeostasis occurs when there is equilibrium in the production and scavenging of ROS. Aghaei et al. (2009) suggested that the increase in stress tolerance correlates with increased antiradical activity. Results of our experiment showed that the induced tetraploids had significantly higher antiradical activity than their diploid progenitors. These results are similar to the reports from Meng et al. (2011), where an increase in antiradical activity resulted in increased stress tolerance in auto-induced tetraploids of turnip compared to their diploid counterparts.

Phenolics are secondary metabolites that influence different physiological processes related to growth and development (Tanase et al., 2019). The production of secondary metabolites is often triggered by drought stress, and studies have reported that increase in the production of phenolic compounds such as quercetin and rutin has contributed to tolerance to drought stress in Hypericum brasiliense (Abreu, Mazzafera, 2005). Results of our experiment showed that the induced tetraploids produced significantly more phenolic compounds and had higher antiradical activities compared to their parental diploids during mild drought. These could play an important role in long term exposure to drought, as the induced tetraploids could be at an advantage over their diploid progenitors.

Plant tolerance to drought occurs via many mechanisms such as dehydration avoidance and dehydration tolerance (Fang, Xiong, 2015). Results from mild drought simulation showed that the cultivars exhibited signs of dehydration avoidance as a first response to drought by reducing their leaf growth. Four induced tetraploids had a significant reduction in leaf growth compared to their diploid counterparts. This response to drought stress involves a cascade of reactions involving many genes at the molecular level; however, duplication of the genetic materials seems to have an advantage over the diploid cultivars in the first response to drought in Westerwolths ryegrass.

Plants respond to water stress by complex mechanism inducing various physiological, morphological, biochemical and molecular changes. These responses are highly varied among plant species and also between cytotypes (Aslam et al., 2015). Leaf chlorophyll fluorescence reflects the integrity of the 
photosynthetic apparatus or photochemical efficiency of the photosystem II in the light reaction of photosynthesis (Kaiser, 1987). Studies have used chlorophyll fluorescence ratio and leaf water content to evaluate the drought response in different grass species (Merewitz et al., 2011; Shukla et al., 2015). In the present study, variations were found in chlorophyll fluorescence across cultivars. Variations were also observed in the relative water content of the diploid and their respective induced tetraploids; however, no significant correlation was found between the traits observed during mild drought.

The correlation analysis between the morphological and physiological parameters (reduction in leaf elongation, relative water content, chlorophyll fluorescence ratio, antiradical activity and phenolic content) at the end of mild drought simulation showed a medium positive correlation between the growth reduction and phenolic contents and strong positive correlation between the antiradical activity and phenolic content $(r=0.75, p \leq 0.01)$. A large group of phenolic compounds have antioxidant properties (Rani et al., 2018), and this could explain why the phenolic content correlated positively with antiradical activity. The correlation between the antiradical activity and phenolic contents at the end of the mild drought with the morphological traits in 2018 field trials characterized by a lower amount of rainfall was estimated. All the morphological traits had a significant medium positive correlation $(p \leq 0.01)$ also was estimated with the antiradical activity and phenolic contents.

Drought is a complex quantitative trait, and previous studies have shown that drought tolerance could vary at different developmental stages (Kron et al., 2008). In addition, the phenotypic response of plants to stress is complex and governed by the interactive effects of factors such as stress duration, genotypes and developmental stage, at which the stress occurs and the intensity of the stress (Obidiegwu et al., 2015). Yet, when working on drought tolerance in wheat cultivars Boutraa et al. (2010) reported that genotypes exhibiting high DPPH (2,2-diphenyl-1-picrylhydrazyl) scavenging activity and high phenolic content at the seed stage continued to show high antiradical activity and phenolic contents at other stages. In this study, the induced tetraploids had more antioxidant and phenolic contents in response to mild drought. This difference in physiological response at the seedling stages could proceed to other developmental stages and contribute to the observed improved performance of the induced tetraploids in the 2018 field trials. However, future work should be done on the DPPH scavenging and total phenolic contents in field trials at various developmental stages.

Wilting is a physiological and morphological response to drought stress that occurs due to the loss of cell turgor pressure, resulting in the drooping of leaves (Tavakol, Pakniyat, 2007). Wilting under drought stress is a common phenomenon, and this visual cue is important for assessing drought-tolerant plants. As a result of the increased reduction in leaf elongation in the induced tetraploids during mild drought, it was assumed that the induced tetraploids will have a lower wilting score than their diploid progenitors; however, two induced tetraploids ('Grazer-4×' and 'Druva-4×') had a higher wilting score despite their high reduction of leaf elongation when compared with their diploid progenitors. There was no significant difference between 'Magloire' and 'Magloire- $4 \times$ ' in the leaf growth reduction, but the induced tetraploid had a higher relative water content, chlorophyll fluorescence ratio and a lower wilting score. This suggests that the 'Magloire-4×' was able to tolerate drought better than their diploid progenitors. This superior trait demonstrated by 'Magloire-4×' was also apparent in the field experiment and could be associated with many factors, including dosage effect, the neofunctionalisation of duplicated genes, increased allelic diversity and mutation buffering (te Beest et al., 2012).

Comparing results from cultivars / induced tetraploids in our field experiment in 2018 and the drought simulation experiment, it is not surprising that the tetraploid cultivars and induced tetraploids with a lower wilting score had better phenotypic scores in the field experiments than the diploid cultivars. However, the induced tetraploids 'Grazer-4×' and 'Druva-4×', which had a high wilting score, still had a better phenotypic character than their diploid progenitors. In the field experiments, the process of dehydration usually progresses slowly and induces the minimal of droughtrelated genes. Conversely, the rapid stress imposition of drought simulation in pots with restricted root zone often triggers greater gene expression (Barker et al., 2005). In addition to the genotypic difference between the cultivars, one possible explanation for the observed high wilting score for 'Grazer- $4 \times$ ' and 'Druva- $4 \times$ ' could be related to plant biomass. They both produced more biomass than their diploid progenitors and hence the plant size could affect their water-use rate. Large plants wilt faster than smaller plants when irrigation is stopped in pot experiments (Blum, 2011), although this is not consistent with other induced tetraploids.

Homeostasis can be described as the ability of organisms to adjust their internal physiological condition when responding to a changing external environment (Wang et al., 2016). In this regards, our empirical data on the phenotypic traits suggested that the tetraploid cultivars and induced tetraploids could be at a homeostatic advantage over their diploid counterparts. This implies that ploidy influences physiological response that improves drought tolerance in Westerwolths ryegrass.

The abundant supply of both diploid and tetraploid forage grass cultivars on the market makes it rather tricky to take an informed decision for the farmer. The breeders, on the other hand, are faced with the neverending challenge to steer the breeding programs to meet the challenges that might arise in the future. Current climatic trends and future models indicate an increase of the areas facing constant or recurrent droughts making breeding for drought-tolerant forage cultivars a top priority.

\section{Conclusions}

1. High dry matter yield and quality associated with resistance to drought is one of the most important criteria in Westerwolths ryegrass breeding. Field trials in 2017 and 2018 clearly demonstrated an inhibition of dry matter production in the diploid cultivars and the respective induced tetraploids in response to drought. However, the induced tetraploids produced more dry matter yield than their diploid progenitors, indicating that the increase in ploidy level affected tolerance to drought.

2. The induced tetraploids of Westerwolths ryegrass had higher antiradical activity and total phenolic content during mild drought periods than their parental diploids. This response correlates with yield under drought conditions and it reflects the potentials of tetraploids in drought adaptability.

3. The climatological predictions expect drought to increase in intensity in many parts of the world. This study produced an interesting induced tetraploid 'Magloire-4×', which was tolerant to drought and 
produced high dry matter yield. Therefore, 'Magloire- $4 \times$ ' has potential in the breeding programs and could be used for crossing and developing new resistant populations.

\section{Acknowledgements}

This study was part of the project funded by the Research Council of Lithuania, grant No. S-MIP-17-24 (GrowGene), and the long-term research program "Genetic and purposeful change of agricultural and forest plants" implemented by the Institute of Agriculture, Lithuanian Research Centre for Agriculture and Forestry.

Received 09072019 Accepted 31012020

\section{References}

1. Abreu I., Mazzafera P. 2005. Effect of water and temperature stress on the content of active constituents of Hypericum brasiliense Choisy. Plant Physiology and Biochemistry, 43: 241-248. https://doi.org/10.1016/j.plaphy.2005.01.020

2. Adams K., Cronn R., Percifield R., Wendel J. 2003. Genes duplicated by polyploidy show unequal contributions to the transcriptome and organ-specific reciprocal silencing. Proceedings of the National Academy of Sciences of the United States of America, 100: 4649-4654. https://doi.org/10.1073/pnas.0630618100

3. Aghaei K., Ehsanpour A., Komatsu S. 2009. Potato responds to salt stress by increased activity of antioxidant enzymes. Journal of Integrative Plant Biology, 51: 10951103. https://doi.org/10.1111/j.1744-7909.2009.00886.x

4. Akinroluyo O., Statkevičiūtė G., Kemešytė V. 2018. Tetraploid Induction in Lolium multiflorum. Brazauskas G. et al. (eds). Breeding grasses and protein crops in the era of genomics. Springer, p. 73-77. https://doi.org/10.1007/978-3-319-89578-9 13

5. Aslam M., Zamir I., Anjum S., Khan I., Tanveer M. 2015. An investigation into morphological and physiological approaches to screen maize (Zea mays L.) hybrids for drought tolerance. Cereal Research Communications, 43 (1): 41-51. https://doi.org/10.1556/CRC.2014.0022

6. Aversano R., Caruso I., Aronne G., De Micco V., Scognamiglio N., Carputo D. 2013. Stochastic changes affect Solanum wild species following autopolyploidization. Journal of Experimental Botany, 64: 625-635. https://doi.org/10.1093/jxb/ers357

7. Barker T., Campos H., Cooper M., Dolan D., Edmeades G., Habben J., Schussler J., Wright D., Zinselmeier C. 2005. Improving drought tolerance in maize. Janick J. (ed.). Plant breeding reviews, vol. 25 , p. 173-253. https://doi.org/10.1002/9780470650301.ch7

8. Blainski A., Lopes G., de Mello J. 2013. Application and analysis of the Folin Ciocalteu method for the determination of the total phenolic content from Limonium brasiliense $\mathrm{L}$. Molecules, 18 (6): 6852-6865.

https://doi.org/10.3390/molecules 18066852

9. Blum A. 2011. Drought resistance - is it really a complex trait? Functional Plant Biology, 38 (10): 753. https://doi.org/10.1071/FP11101

10. Blum A., Tuberosa R. 2018. Dehydration survival of crop plants and its measurement. Journal of Experimental Botany, 69 (5): 975-981.

https://doi.org/10.1093/jxb/erx445

11. Bothe A., Westermeier P., Wosnitza A., Willner E., Schum A., Dehmer J., Hartmann S. 2018. Drought tolerance in perennial ryegrass (Lolium perenne L.) as assessed by two contrasting phenotyping systems. Journal of Agronomy and Crop Science, 204 (4): 375-389. https://doi.org/10.1111/jac.12269

12. Boutraa T., Akhkha A., Al-Shoaibi A., Alhejeli M. 2010. Effect of water stress on growth and water use efficiency (WUE) of some wheat cultivars (Triticum durum) grown in Saudi Arabia. Journal of Taibah University for Science, 3: 39-48. https://doi.org/10.1016/S1658-3655(12)60019-3

13. Brand-Williams W., Cuvelier M., Berset C. 1995. Use of a free radical method to evaluate antioxidant activity. LWT Food Science and Technology, 28: 25-30. https://doi.org/10.1016/S0023-6438(95)80008-5
14. Burns G., Gilliland T., Grogan D., Watson S., O'Kiely P. 2013 Assessment of herbage yield and quality traits of perennial ryegrasses from a national variety evaluation scheme. The Journal of Agricultural Science, 151: 331-346. https://doi.org/10.1017/S0021859612000251

15. Dabkevičienè G., Kemešytè V., Statkevičiūtè G., Lemežienè N., Brazauskas G. 2017. Autopolyploids in fodder grass breeding: induction and field performance. Spanish Journal of Agricultural Research, 15 (4): e0706. https://doi.org/10.5424/sjar/2017154-11357

16. Dai A. 2013. Increasing drought under global warming in observations and models. Nature Climate Change, 3 (1): 52-58. https://doi.org/10.1038/nclimate1633

17. Dar T., Raina S., Goel S. 2013. Molecular analysis of genomic changes in synthetic autotetraploid Phlox drummondii Hook. Biological Journal of the Linnean Society, 110: 591-605. https://doi.org/10.1111/bij.12154

18. Ergon Å., Seddaiu G., Korhonen P., Virkajärvi P., Bellocchi G., Jørgensen M., Østrem L., Reheul D., Volaire F. 2018. How can forage production in Nordic and Mediterranean Europe adapt to the challenges and opportunities arising from climate change? European Journal of Agronomy, 92: 97-106. https://doi.org/10.1016/j.eja.2017.09.016

19. Fang Y., Xiong L. 2015. General mechanisms of drought response and their application in drought resistance improvement in plants. Cellular and Molecular Life Sciences, 72: 673-689. https://doi.org/10.1007/s00018-014-1767-0

20. Gao R., Wang H., Dong B., Yang X., Chen S., Jiang J., Zhang Z., Liu C., Zhao N., Chen F. 2016. Morphological, genome and gene expression changes in newly induced autopolyploid Chrysanthemum lavandulifolium (Fisch. ex Trautv.) Makino. International Journal of Molecular Sciences, 17 (10): E1690. https://doi.org/10.3390/ijms17101690

21. Helgadóttir Á.,Aavola R., Isolahti M., Marum P., Persson C., Aleliūnas A., Brazauskas G., Krisjánsdóttir T. A., Asp T. Rognli O. A. 2018. Adaptability and phenotypic stability of Lolium perenne L. cultivars of diverse origin grown at the margin of the species distribution. Journal of Agronomy and Crop Science, 204 (5): 493-504. https://doi.org/10.1111/jac.12273

22. Humphreys M., Feuerstein U., Vandewalle M., Baert J. 2010. Ryegrasses. Boller B. et al. (eds). Handbook of plant breeding: fodder crops and amenity grasses. Springer, p. 211-260. https://doi.org/10.1007/978-1-4419-0760-8 10

23. Kaiser W. M. 1987. Effects of water deficit on photosynthetic capacity. Physiologia Plantarum, 71 (1): 142-149. https://doi.org/10.1111/j.1399-3054.1987.tb04631.x

24. Katepa-Mupondwa F., Christie B., Michaels T. 2002. An improved breeding strategy for autotetraploid alfalfa (Medicago sativa L.). Euphytica, 123: 139-146. https://doi.org/10.1023/A:1014488307000

25. Kemesyte V., Statkeviciute G., Brazauskas G. 2017. Perennial ryegrass yield performance under abiotic stress. Crop Science, 57: 1935. https://doi.org/10.2135/cropsci2016.10.0864

26. Kron A., Souza G., Ribeiro R. 2008. Water deficiency at different developmental stages of Glycine max can improve drought tolerance. Bragantia, 67 (1): 43-49. https://doi.org/10.1590/S0006-87052008000100005

27. Liu B., Wendel J. 2003. Epigenetic phenomena and the evolution of plant allopolyploids. Molecular Phylogenetics and Evolution, 29: 365-379. https://doi.org/10.1016/S1055-7903(03)00213-6

28. Luo J. 2010. Breeding for water-saving and droughtresistance rice (WDR) in China. Journal of Experimental Botany, 61 (13): 3509-3517. https://doi.org/10.1093/jxb/erq185

29. Meng H., Jiang S., Hua S., Lin X., Li Y., Guo W., Jiang L. 2011. Comparison between a tetraploid turnip and its diploid progenitor (Brassica rapa L.): the adaptation to salinity stress. Agricultural Sciences in China, 10: 363-375. https://doi.org/10.1016/S1671-2927(11)60015-1

30. Merewitz E., Gianfagna T., Huang B. 2011. Photosynthesis, water use, and root viability under water stress as affected by expression of SAG12-ipt controlling cytokinin synthesis in Agrostis stolonifera. Journal of Experimental Botany, 62 (1): 383-395. https://doi.org/10.1093/jxb/erq285 
31. Obidiegwu E., Bryan J., Jones G., Prashar A. 2015. Coping with drought: stress and adaptive responses in potato and perspectives for improvement. Frontiers in Plant Science, 6: 1-23. https://doi.org/10.3389/fpls.2015.00542

32. Osborn T. C., Pires J. C., Birchler J. A., Auger D. L., Chen Z. J., Lee H. S., Comai L., Madlung A., Doerge R. W., Colot V., Martienssen R. A. 2003. Understanding mechanisms of novel gene expression in polyploids. Trends in Genetics, 19 (3): $141-147$. https://doi.org/10.1016/S0168-9525(03)00015-5

33. Ramsey J., Schemske D. 2002. Neopolyploidy in flowering plants. Annual Review of Ecology, Evolution, and Systematics, 33: 589-639. https://doi.org/10.1146/annurev.ecolsys.33.010802.150437

34. Rani R., Arora S., Kaur J., Manhas R. 2018. Phenolic compounds as antioxidants and chemopreventive drugs from Streptomyces cellulosae strain TES17 isolated from rhizosphere of Camellia sinensis. BMC Complementary and Alternative Medicine, 18 (1): 1-15. https://doi.org/10.1186/s12906-018-2154-4

35. Renny-Byfield S., Wendel F. 2014. Doubling down on genomes: polyploidy and crop plants. American Journal of Botany, 101 (10): 1711-1725. https://doi.org/10.3732/ajb.1400119

36. Sattler M., Carvalho C., Clarindo W. 2016. The polyploidy and its key role in plant breeding. Planta, 243: 281-296. https://doi.org/10.1007/s00425-015-2450-x

37. Schneider C. A., Rasband W. S., Eliceiri K. W. 2012. NIH image to ImageJ: 25 years of image analysis. Nature Methods, 9: 671-675. https://doi.org/10.1038/nmeth.2089

38. Shukla V., Ma Y., Merewitz E. 2015. Creeping bentgrass responses to drought stress and polyamine application. Journal of the American Society for Horticultural Science, 140: 94-101. https://doi.org/10.21273/JASHS.140.1.94

39. Smart R., Bingham G. 1974. Rapid estimates of relative water content. Plant Physiology, 53: 258-260. https://doi.org/10.1104/pp.53.2.258

40. Soltis E., Soltis S., Tate A. 2003. Advances in the study of polyploidy since plant speciation. New Phytologist, 161 (1): 173-191. https://doi.org/10.1046/j.1469-8137.2003.00948.x
41. Sugiyama S.-I. 2005. Polyploidy and cellular mechanisms changing leaf size: comparison of diploid and autotetraploid populations in two species of Lolium. Annals of Botany, 96: 931-938. https://doi.org/10.1093/aob/mci245

42. Tanase C., Bujor O., Popa V. 2019. Phenolic natural compounds and their influence on physiological processes in plants. Watson R. R. (ed.). Polyphenols in plants ( ${ }^{\text {nd }}$ ed.). Academic Press, p. 45-58. https://doi.org/10.1016/B978-0-12-813768-0.00003-7

43. Tavakol E., Pakniyat H. 2007. Evaluation of some drought resistance criterion at seedling stage in wheat (Triticum aestivum L.) cultivars. Pakistan Journal of Biological Sciences, 10 (7): 1113-1117. https://doi.org/10.3923/pjbs.2007.1113.1117

44. te Beest M., Le Roux J., Richardson D., Brysting A., Suda J., Kubešová M., Pyšek P. 2012. The more the better? The role of polyploidy in facilitating plant invasions. Annals of Botany, 109: 19-45. https://doi.org/10.1093/aob/mcr277

45. Trnka M., Hlavinka P., Semenov M. 2015. Adaptation options for wheat in Europe will be limited by increased adverse weather events under climate change. Journal of the Royal Society Interface, 12 (112): 1-7. https://doi.org/10.1098/rsif.2015.0721

46. Wang X., Cai X., Xu C., Wang Q., Dai S. 2016. Droughtresponsive mechanisms in plant leaves revealed by proteomics. International Journal of Molecular Sciences, 17 (10): E1706. https://doi.org/10.3390/ijms17101706

47. WRB. 2014. World reference base for soil resources. World Soil Resources Reports No. 106. FAO, p. 187-189.

48. Yates S., Jaškūnè K., Liebisch F., Nagelmüller S. Kirchgessner N., Kölliker R., Walter A., Brazauskas G., Studer B. 2019. Phenotyping a dynamic trait: leaf growth of perennial ryegrass under water limiting conditions. Frontiers in Plant Science, 10: 344. https://doi.org/10.3389/fpls.2019.00344

49. Zandalinas S., Mittler R., Balfagón D., Arbona V., GómezCadenas A. 2018. Plant adaptations to the combination of drought and high temperatures. Physiologia Plantarum, 162: 2-12. https://doi.org/10.1111/ppl.12540

ISSN 1392-3196 / e-ISSN 2335-8947

Zemdirbyste-Agriculture, vol. 107, No. 2 (2020), p. 161-170

DOI 10.13080/z-a.2020.107.021

\title{
Skirtingo ploidiškumo vienametès gausiažiedès svidrès veislių atsakas ị sausros stresą
}

\author{
O. K. Akinroluyo, K. Jaškūnė, V. Kemešytė, G. Statkevičiūtė
}

Lietuvos agrarinių ir miškų mokslų centro Žemdirbystės institutas

\section{Santrauka}

Sausros stresas yra vienas svarbiausių abiotinių veiksnių, sukeliančių reikšmingus žemès ūkio produkcijos nuostolius. Remiantis klimato kaitos modeliais, ateityje ši problema tik aštrès. Poliploidiniai augalai dažnai yra atsparesni abiotiniams stresams. Siekiant ịvertinti ploidiškumo ịtaką augalų atsparumui, eksperimento metu buvo palygintas vienametès gausiažiedės svidrès (Lolium multiflorum spp. multiflorum) diploidinių veislių ir autotetraploidinių populiacijų atsakas ị sausros stresą. Siekiant užtikrinti kuo didesnį genetinị skirtingo ploidiškumo augalų vienodumą, autotetraploidinès populiacijos buvo indukuotos iš diploidinių veislių. Chromomosomų duplikacijos įtaka augalo morfologiniams požymiams ir sausros atsakui buvo vertinta 2017 ir $2018 \mathrm{~m}$. natūraliomis sąlygomis lauko eksperimente ir kontroliuojamos aplinkos sąlygomis fitotrone, simuliuojant trumpalaikę sausrą. Lauko eksperimente tetraploidiniai augalai buvo aukštesni, formavo ilgesnius žiedynus ir davė didesnị sausųjų medžiagų derlių, palyginus su diploidinėmis veislėmis. Šie esminiai $(p<0,05)$ skirtumai tarp ploidiškumo grupių ypač išryškejjo sausringais $2018 \mathrm{~m}$.

Kontroliuojamomis sąlygomis nustatyta reikšminga chlorofilo fluorescencijos santykio (Fv:Fm), santykinio vandens kiekio lapuose ir lapų vytimo ịverčių variacija tarp genotipų ir ploidiškumo grupių. Reikšmingai didesnis indukuotų tetraploidų antioksidacinis aktyvumas ir fenolinių junginių kiekis, palyginus su diploidais, ir esminė šių požymių koreliacija su augalų fenotipiniais požymiais lauko eksperimente $2018 \mathrm{~m}$. patvirtino poliploidiškumo ịtaką vienametės gausiažiedès svidrès augalų atsparumui sausrai.

Reikšminiai žodžiai: morfologiniai požymiai, tetraploidai, trumpalaikè sausra. 